HC 単用施蒋区（A 1，A 2) 亿較へ，第 2 此代成出招 上び㭃虫に対し効果が認められるが，第 3 仩代㭃虫時代 には差がなくなつた。また混用施莧区はパラチオン拉よ びパラチオン NAC 混用散布区（C2とB $1 ， \mathrm{~B} 2$ の比 皎）に比べる上，やや效果が少るものの上うである。7 月中旬パラチオン1回のみの政布は（C 1) 7 月末にお
けるッマグロヨコバイの発生を充分おさえていないと考 无ら机る，他のウンカ類について屯調査したが発生が少 かつたので省略する。

\section{4. 本田（後期）集団水中施薬試験}

第 6 表のとおり防除を行なつた．施薬区は今回は全酒

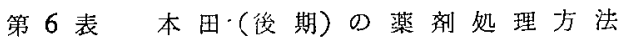

\begin{tabular}{|c|c|c|c|c|c|c|c|c|}
\hline 別 & 处 理 薬 剂 & $10 \mathrm{a}$ 当使用量 & 処理月日 & 处 & 理 & $y_{j}$ & 法 & \\
\hline 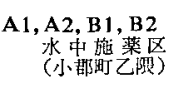 & 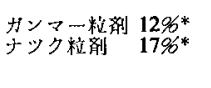 & 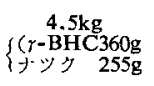 & 8月22 24日 & \multicolumn{5}{|c|}{ 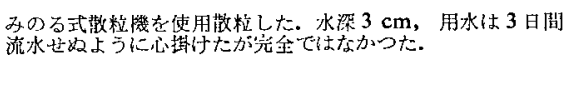 } \\
\hline 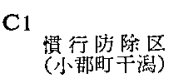 & 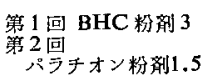 & $\begin{array}{l}3 \mathrm{~kg} \\
3 \mathrm{~kg}\end{array}$ & $\begin{array}{l}\text { 8月 } 23 \text { 日 } \\
\text { 8月30日 }\end{array}$ & \multicolumn{5}{|c|}{ 動力敬枌機, 手勘散枌機を使用全面敬布 } \\
\hline 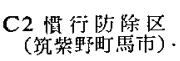 & パラチオン搅珮 & 1,000 倍 $70 l$ & 8月27日 & \multicolumn{5}{|c|}{ 動力貲竓機を使用全面散布 } \\
\hline
\end{tabular}

同一薬剂で処理した。調查はメイチュウについては出想 直後（9月20日）之収穫期（10月30日）の2 回, 前期 と同じ聚領で各围場 20 怢について行なつた. ウンカ類 屯前期上同棣 8 月 28 日，10月 10 日の 2 回（10月 10 日

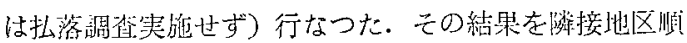

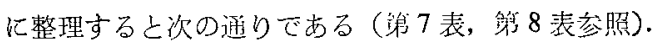

第 7 表 ニカメイチュウ第 2 世代の被寒荎率の 消長調疽成績

\begin{tabular}{|c|c|c|c|c|c|c|}
\hline 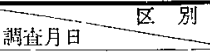 & C 2 & B 1 & B 2 & A 1 & A 2 & C 1 \\
\hline 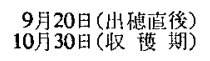 & $\begin{array}{l}0.1195 \\
0.92\end{array}$ & $\begin{array}{l}0.06 \\
0.29\end{array}$ & $\begin{array}{l}0.14 \\
0.12\end{array}$ & $\begin{array}{l}0.04 \\
0.11\end{array}$ & $\begin{array}{l}0.04 \\
0.07\end{array}$ & $\begin{array}{l}0.12 \\
0.43\end{array}$ \\
\hline
\end{tabular}

第 8 表 ツマグロヨコバイの発生消長調查成緹

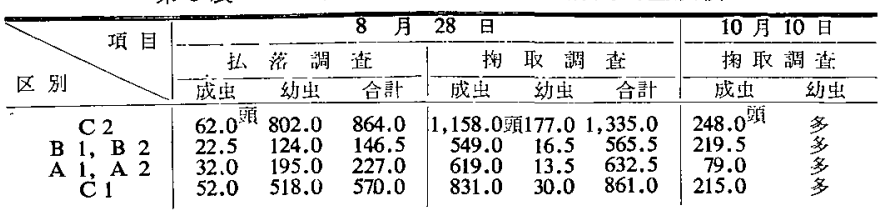

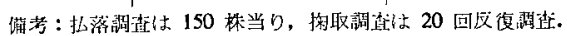

二カメイチュウ：第 2 世代に対する水中於薬の效果は パラチオン乳剂 1 回散布と BHC およびパラチオン粉剂 の2回散有に較べてむしろ優れている㑯问を示した。

ッマグロヨコバイ：NAC 混用の水中施蒋の效果はパ

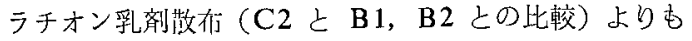
直後の效果は陆れている上うである.しかし，10月上旬 に発生する第 5 忏代の㭃虫㥓何れの区屯極めて多くみら
れ，その㕮果は期待できないものと考えられた。

\section{5. 結}

論

この試験より苗代における NAC, BHC 混合煜劌の水 中施薬はッマグロヨコバイに対しては，NAC 2 回，パ ラチオン 1 回の 3 回散有と大差ない屯の上考光られる. ヒメトビウンカにもかなり效果があり，特に幼虫の発生 は䜅められなかつたが，ウイルス病防除の效果について

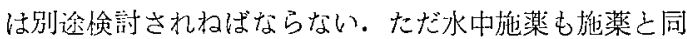
時に洼代周辺防除を実推する力がよいと考えられる。

本田前期におりる試験では蒙雨により局地的に薬剤の 流亡があつたが，全体的にみ机ば，供試し た BHC 粒剂はニカメイチニウに対し，か なり安定した効果がみられ充分荚用化でき るむのと考えられる．乙の埸合 PCP との 泥用は施楽時期などで問題があるう。NA Cの混用施薬は本田初期のウイルス病防除 には有効と思われる。

第 2 怔代二カメイチュウに対しては，この量で充分顕 著な㱛果をあげ得るものと思われる。本田後期の本試験 では，多少実施がおくれたのでッマグロヨコバイ成虫に 対する NAC 混用施薬の刘果は䫓著ではなかつた。しか

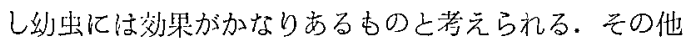
のウンカ類については発生が少く検討できなかつた。

\title{
集団水中施薬による稲作害虫防除の農家経済におよぼす影響
}

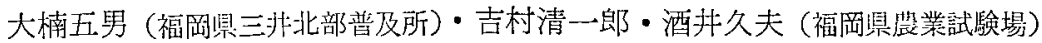
黒 瀬 禎 三 (福岡県㖘業改良課)

\section{はじめに}

福岡県小郡町に救いて苗代から本田までの省力防除と
いう立前から，BHC 剂および NAC 剂の水中施楽によ る集団防除関する一連の試験を実施し，その防除效果 や侵家経济におよ括す影響を従来の人竞毒性の強いパラ 
チオン剂による共同防除亡，比較検封した。ことでは，

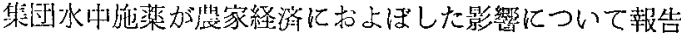

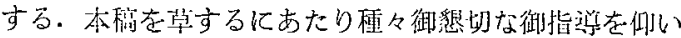

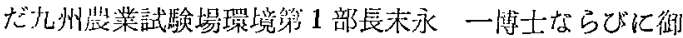
泇力を煩わした三笠化学に対し澡甚の謝意を婊する。

\section{1. 試験部落の営農概況}

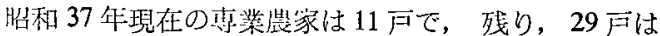
第一枆，第二種兼業寝家である。

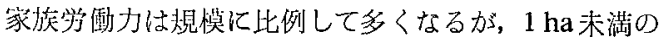

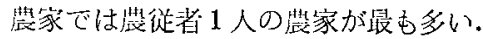

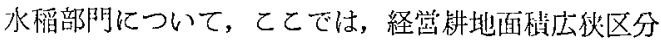

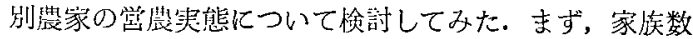
は経営耕地面啃が $50 \mathrm{a}$ 末満の農家6戸の平均は 4 人で，

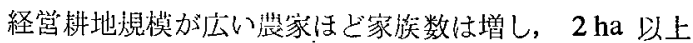

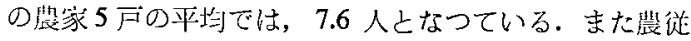
者数では 1 ha未满の淑家で 1 人強, 2 ha 以上で 3.6 人 となつている。

水榣の $10 \mathrm{a}$ 当り収皇は昭和36年上り，昭利 37 年が40 戸の平均で $60 \mathrm{~kg}$ 以上多く，階層の差は認められない。

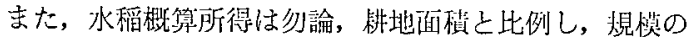
大きい装集はど所得す高い。10 a 当り粗収入は 3.8 万円 程度の㖘家が多い。

\section{2. 水稻肥培管理学㗢時間の比較}

胉和 36 年㐨よび昭和 37 年の学墈時間を比較すると第 1 図のとおりである。

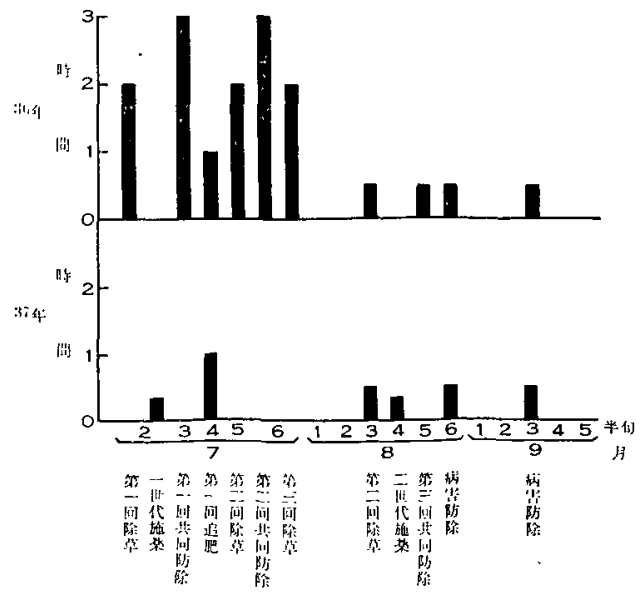

第 1 図昭和36年と 37年の水稲肥培管理学僄時間の比較 (10 $a$ 当り)

第 1 図で明らかなように水中施薬による害虫防除（解 1 世代の場合は水中揓薬と PCP を混合散粒したので除 草屯含まれる）の労働時間はニカメイチニウ第 1 代代を 主とした稻作前期に㨟いて 10 a 当り 20 分，二カメイチ ユウ第 2 世代を主とした稲作後期に利いて 20 分, 計 40

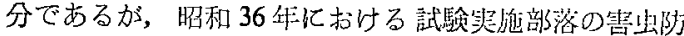
除の労働は稻作前期 6 時間，稲作後期 30 分，計 6 㭙間 30 分で，除草も會めれば 12 脚間 30 分であつた。 この ように水中施薬（除草む念む）に上つて学力が節娍され 器外就学が多くなつたが，その就多先は福同市であり， 就学者时晨莱経営主6 割, 長男が4割である。

また，労働抹段㧍よび生活の変化も水中施薬のみによ

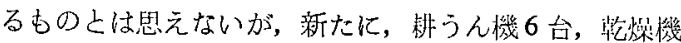
13 台，テレビ7台と多くもの屯のが導入されている.

3. 試験部落における昭和 37 年（水中施薬区）と昭 和 36 年 (慣行防除) との費用の比較

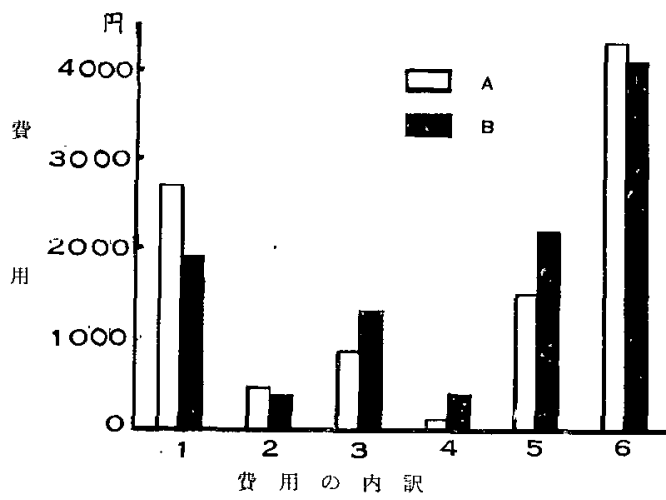

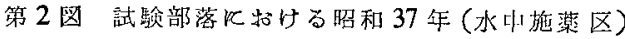
と 36 年 (慣行防除) との留用の比較

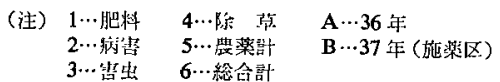

第 2 図で明らかなように病䇺用農薬は施薬区が約 210

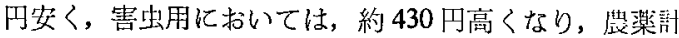
で施楽区が約 550 円高くなつているが，肥料を会めた合

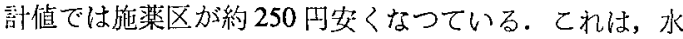

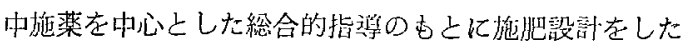
ためで，肥料費が 1 户平均 6,800 円少なくなつた。

\section{4. 省力によつて生じたと思われる農外就労日数と耕 地階層別分布}

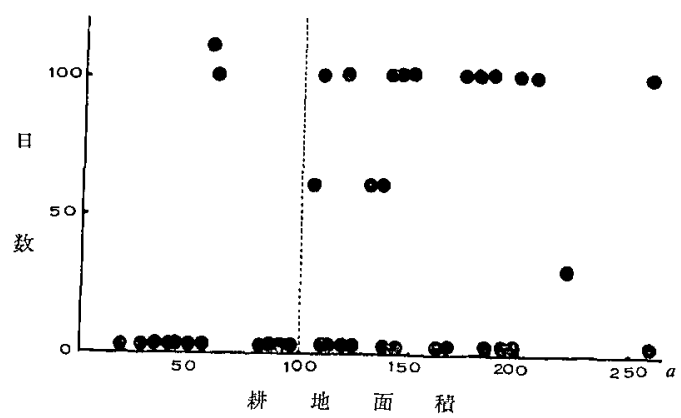

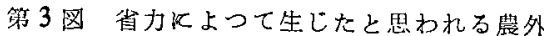
就労日数と耕地階尿别分布 


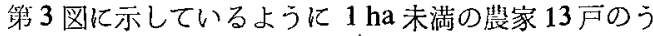

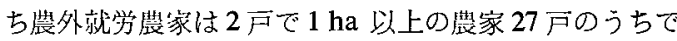

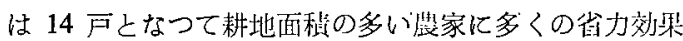
が現われているようである.装外就労の日数は水穱本田 期間中で，扣よそ100日がその限度となつている゙が，50 日程度の装家む5〜6戸あり，てのととは水中施蒋が装 冢に装外収入の㙨会を与えるという，装家経済にとつて プラスの画に動いたと言えるだろう。

5. 本田期における農外就労の収入

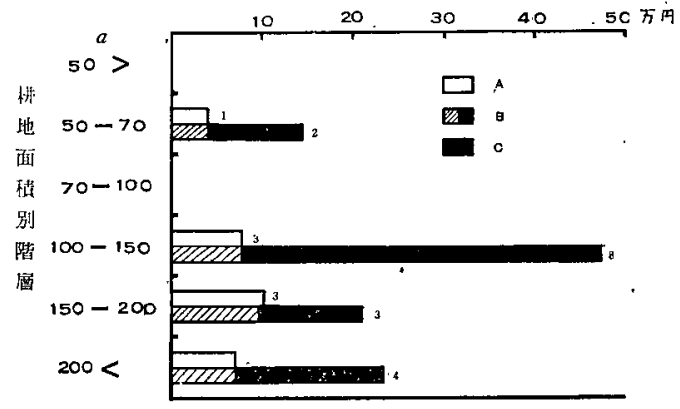

第 4 図本田期間に括ける農外就学の収入

$$
\begin{aligned}
& \text { A } \cdots 36 \text { 年收入 } \\
& \text { B ‥37 年收入 } \\
& \text { C…施箱によるむのと䍐われる叫入 }
\end{aligned}
$$

第 4 図で明らかなように，昭和 36 年に拈いては 2 ha

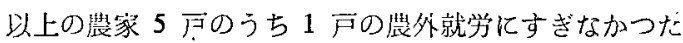
が，昭和 37 年においては 4 戸となつた。他の装家階層 でもこの傾后がはつきり現われている。なお，1 ha以下

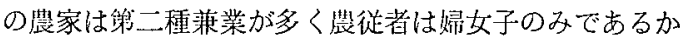
ら, 省力效果が装外就労という然で圐われていない，し たがつて，前年には13 月のうち 1 戸であつたのが昭和

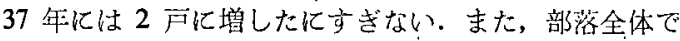
みると 40 戸のうち昭和 36 年は流外就労 8 户で, 286,000 円であつたのが，昭和 37 年は 17 戸で 1,054,000 円上增 加した.
これは，本田期間の㕩虫防除および除草から完全に解 放されたためである。

炤和 37 年は, はじめての水中施薬実㸝の作であつた だけに装家は節娍された学力をとりあえず，装外就然に

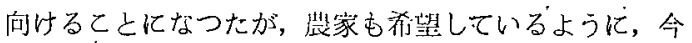
後如経堂腉惧を搪大することに问うのが，好ましいと思 われる。

\section{6. 昭和 36 年における耕地の移動と 農家の 経営拡大 への希望}

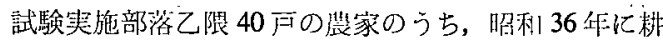
地を売つた䢃家 13戸（河川工事によるむのも含む）で 水田を増玑した獎家は2 戸にすぎないが，今後は 21 戸

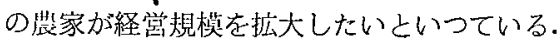

経栄規模拡大の力台は水田を增すことを希望している

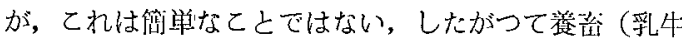
や豚）を拡大または新たに導入する計画をたてている搰 策が 7 局ある。

\section{む す び}

水中施楽を中心とした屯る屯ろの萇蒋の完全駆使によ

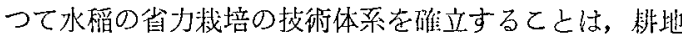
の桩大，家畗の獎入などによつて選排的経営の桩大を計

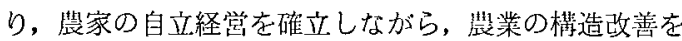
進めるものと思われる。乙の試験は水田作地帶における 構造改善の“きつかけ”加等虫防除のための水中施薬・ 除草剂施用によつて上えられつつあることを実証する 1 例之見做されよう。しかし，とのたびの調查は㕩出およ

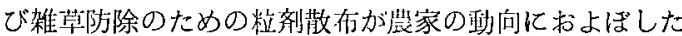
一面を見たにすぎないのて，今後さらに経営診断的な分 析を行なうことによつて経営設訪を樹立し，装業の構造 改善の発屡過程を検討しなりればならないと思つてい る.

\section{本田において水稻を害するミミズの防除について}

\section{立 石 署（福岡紧農業試験場）・白水一義（粕屋地区病害出防除所）}

水稲を㕩するミミズ類の中で，直插田や苗代に発生す

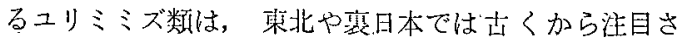
れ，防除法や種類について多くの研究が行なわれている が，本田に発生し稲の根株飞集まり被㫪を与えるミミズ 類について報告されたものは少なく，村上（1924）は 高知䍘飞打いて苗代や本田に発生する，Allolobophora japonica の形態とその被慧について記録し，山口(1934) 遠滕(1937)，大淵（1938）らは北海道において水田に発
生して水稻を管する Heretime 属のミミズについて報告 しているままた最近では吉村 (1962) が福岡県で水稲を 害するミミズの一種の被羖について報告している.

筆者らがここで報告するミミズは，さきに吉村が報告 したものと同一種であり，発生地の福岡罧粕屋郡雓栗町 大字萩尾では被害甚しく，数年前からミミズの防除対策 が問題となつていた。・したがつて，篗者らは本田期任発 生するミミズの防除法を劣明するため，1961１962 年: 